Marquette University

e-Publications@Marquette

Economics Faculty Research and Publications

Economics, Department of

$1-1-2002$

\title{
Corporations and Structural Linkages in World Commerce
}

Joseph P. Daniels

Marquette University, joseph.daniels@marquette.edu

John B. Davis

Marquette University, john.davis@marquette.edu

Published version. "Corporations and Structural Linkages in World Commerce," in The World Trade Organization in the New Global Economy: Trade and Investment Issues in the New Millennium. Eds. Alan M. Rugman and Gavin Boyd. Cheltenham, ENG: Edward Elgar Publishing, 2002: 70-94. Publisher Link. C 2002 Edward Elgar Publishing. Used with permission. 


\title{
4. Corporations and structural linkages in world commerce
}

\author{
John B. Davis and Joseph P. Daniels
}

The Millennium Round of multilateral negotiations under the auspices of the World Trade Organization (WTO) confronts international trade and investment issues that are more complex and intractable than those in past rounds on account of increasing structural and policy interdependencies between the industrialized nations. Negotiators will have to think not only in terms of trade and investment between separate nations but also in terms of a system of production that operates across nations. In previous rounds, liberalizing international trade dominated the agendas. But international trade and investment have bccome more highly interlinked in the last decade, so that it has become difficult to consider trade liberalization apart from capital flows. At the same time, the issue of liberalizing international financial flows has been complicated by the massive expansion in the 1990s of portfolio capital flows and by financial crises in Asia and clsewhere.

This chapter consequently examines international trade and investment linkages in terms of long-term structural change, tying this to corporate strategies responding to and underlying this change. Our principal subject is the theory of international production and the emerging system of international production, and we comment on policy initiatives regarding trade and investment generated by increased recognition of their interlinked character.

International production has been investigated within at least six branches of theory: international capital movements, trade, location, industrial organization, innovation, and the frrm (Cantwell et al., 1986). Various theories of international production investigate different questions posed in theoretical branches they draw upon, some taking macroeconomic and others microeconomic perspectives. The theory of international capital movements and foreign direct investment (FDI), especially where it bears on balance of payments and exchange rate effects, has mainly a macroeconomic focus, whereas the theory of the transnational corporation (TNC) is more microeconomic. Both subjects, however, concern closely related matters, and accordingly understanding important issues in international production generally requires an cclcetic approach, as argued by Dunning (1977, 198 I, 
1988). Our focus is restricted to economics and international business, and does cover social and cultural issues.

\section{CHAPTER OUTLINE}

First we describe a number of key structural developments, to portray general trends in globalization. ' These structural developments concern: the relation of world FDI flows to world trade flows; the dominance of Triad trade and FDI llows in the world economy; the importance of mergers and acquisitions (M\&As) in world FDI; and the geographical and sectoral distribution of FDI and cross-border M\&A. We conclude this section with a discussion of the relationship between trade and investment as substitutes and/or complements.

Next we turn to TNCs as a principal vehicle of globalization processes, and explain how the strategies of major firms in the world economy are shaped by their need to operate in foreign locations. The current state of trade negotiations has given added importance to international firms expanding through FDI. We then emphasize that firm search and deliberation costs, as transaction costs, are particularly important to TNCs, and argue that TNCs become 'embedded' in host social and business networks as they establish foreign affiliates. This 'embeddedness' helps to account for the structural changes and developments described earlier, particularly the concentration of FDI in the Triad, where business networks are generally highly developed. To illustrate the implications of this for the relationship between trade and investment, we return to the topic of trade and investment as substitutes or complements, and discuss three cases showing how firms' I'DI affects exports and imports.

Finally, we discuss economic policy toward FDI and TNCs, particularly in connection with recent unsuccessful efforts to establish the Multilateral Agreement on Investment (MAI). We first consider debate about the national loyalties of TNCs and the impact of liberalized capital flows. We then distinguish between short-term and long-term investment flows, and argue that liberalization of the latter can be in the interest of host countries as TNCs become embedded in them. We then discuss the difference between national competitiveness and the competitiveness of a nation's firms, and make a general case for an international agreement at least along the lines of the MAI. This section closes with an argument in favour of a collection of piecemeal changes that taken together will accomplish much of what was intended by the MAI, and will also create an agenda for more comprehensive reform. 


\section{EVIDENCE OF STRUCTURAL CHANGE}

The collapse of the Bretton Woods system ushered in a new era of globalization, with capital market liberalization beginning in the mid-1970s in the United States and Catrada. The process continued, though unevenly, throughout the remainder of the twentieth century as other developed nations began removing and reducing capital barriers in the 1980s (Williamson and Mahar, 1998). Many developing countries followed suit, although it was a forwardreverse-forward process for some. The risks and rewards became clear as the century came to a close. Long-term capital flows were concentrated in the developed nations, increasing their global production capacity and providing access to lucrative consumer markets. Developing and emerging nations gained jobs created by FDI, but also suffered extreme financial crises created by hotmoney or portfolio flows.

Meanwhile the growth of global trade gradually declined, while foreign direct investment increased. At the same time, different stages of the production processes moved to different world locations, in a 'disintegration' of production as a means to greater global integration (Feenstra, 1998). In this section we focus on developments in trade and capital markets over the last decade. We present the stylized facts only, relating these patterns to strategies and theories of transnationals in the following section.

\subsection{World FDI Flows Relative to World Trade Flows}

In spite of declining transportation costs and advances in telecommunications technology, the rate of growth in world exports has decreased during the last thirty years. As shown in Table 4.1, five-year growth rates in world exports have declined from a high of 24 per cent in the early 1970 s to single digit gains in the 1990s. The long-delayed conclusion to the Uruguay Round of

Table 4.1 Periodic growth of world FDI and exports

\begin{tabular}{lccc}
\hline & FDI inflows & FDI outfows & World cxports \\
\hline $1971-1975$ & 19.8 & 17.3 & 24 \\
$1976-1980$ & 18.5 & 17.4 & 18.1 \\
19811985 & 2.1 & 2.4 & -0.56 \\
$1986-1990$ & 31.5 & 34.6 & 14.5 \\
$1991-1995$ & 11.3 & 9.2 & 8.3 \\
$1996-1998$ & 25.6 & 22.8 & 2.2 \\
\hline
\end{tabular}

Source: UNCTAD tandbook of Statistics (2000). 
trade negotiations, the loss of Presidential fast-track authority in the United States, recent WTO skirmishes, and the lack of $\mathbf{G 7}$ leadership suggests that further gains in world trade are more likely to come from regional and bilateral agreements than from multilateral pacts.

Capital flows have expanded over this same period in a climate of liberalization and gradual harmonization of national tax policies and accounting rules. FDI rates of growth now significantly surpass trade flow rates of growth. As illustrated in Table 4.1, the change hegins after the worldwide recession and the Latin American debt crises of the early 1980s. Further gains in economic liberalization are likely to stem from the expansion of international production fuelled by high rates of FDI as opposed to increased multilateral trade liberalization.

\subsection{Iriad 'Trade and HDI Flows}

Figure 4.1 illustrates Triad and rest-of-world (ROW) shares of world exports. During the last thirty years, the Triad has consistently contributed 60 to 70 per cent of total world exports. Higure 4.2 shows inward FDI flows for the Triad and the ROW for the last thirty years. Though the average inward FDI flow to the 'I'riad is 60 to 70 per cent of the total, these inflows demonstrate a fair amount of variability, perhaps reflecting the Latin American debt crises of the 1980s and the financial crises of the late 1990s, and reveal a short-lived

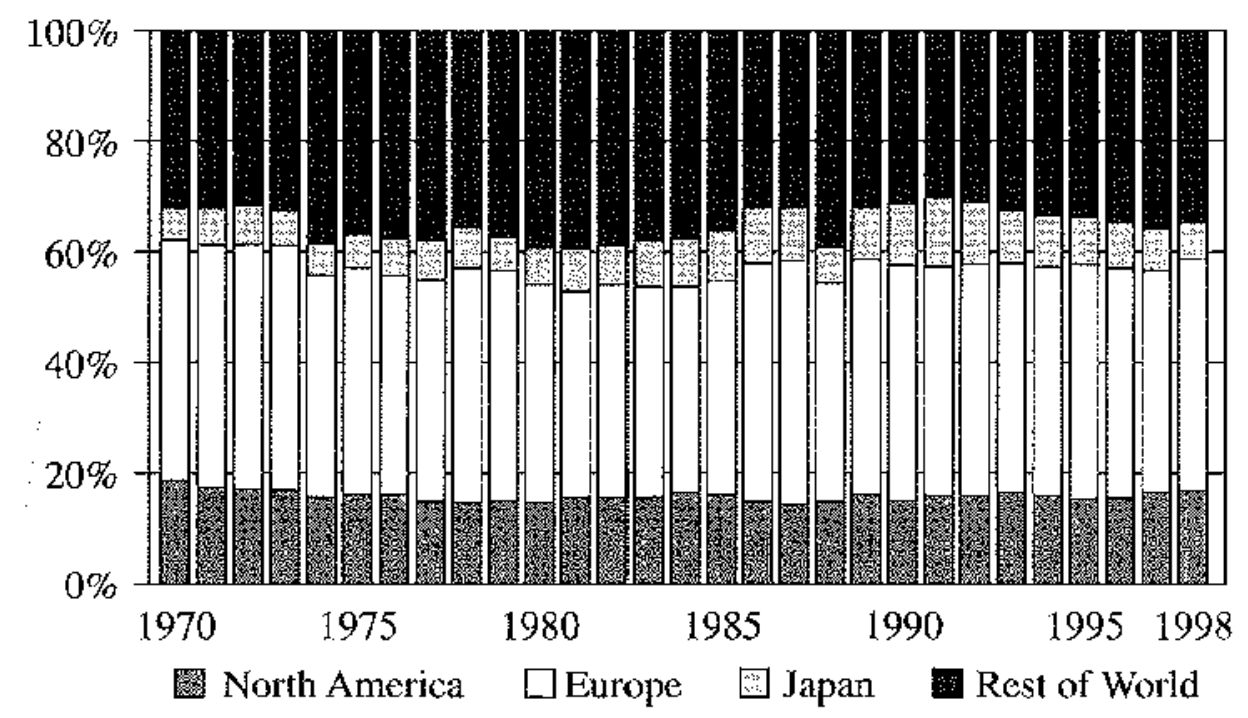

Source: UNCTAD Handbook of Statistics (2000).

Figure 4.1 World exports: Triad proportion of total 


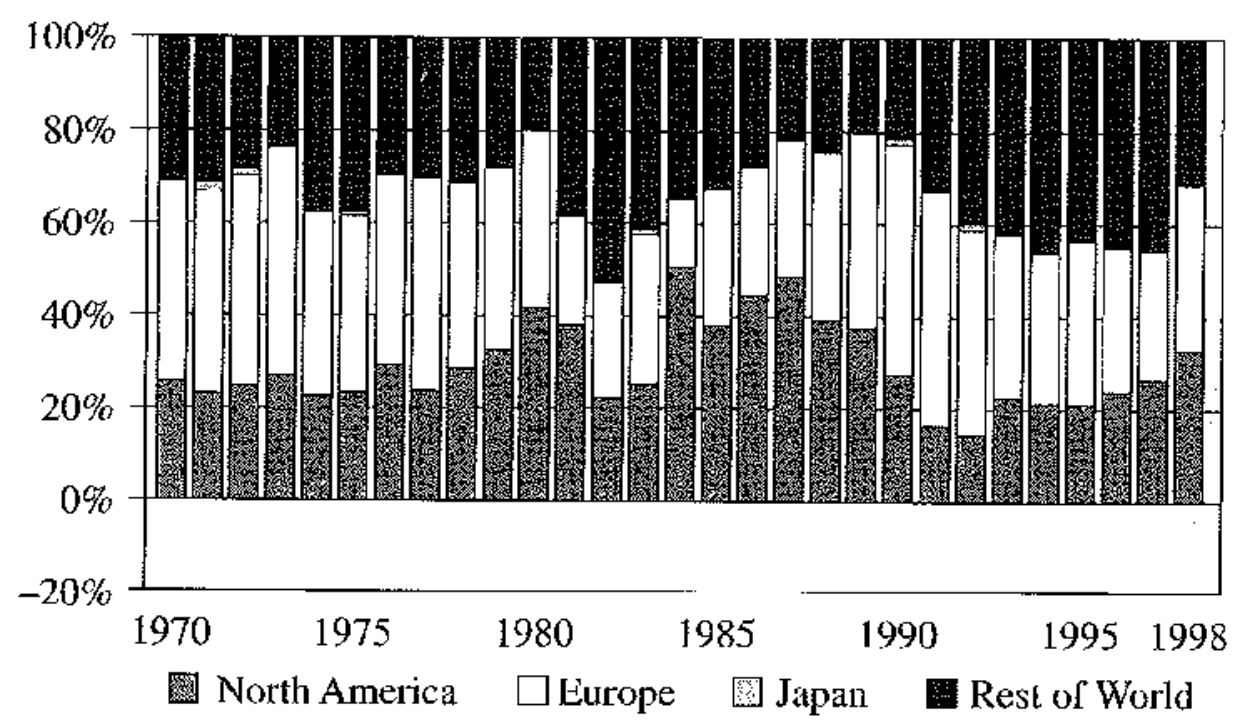

Source: UNCTAD Handbook of Statistics (2000).

Figure 4.2 Inward FDI flows: Triad proportion of total

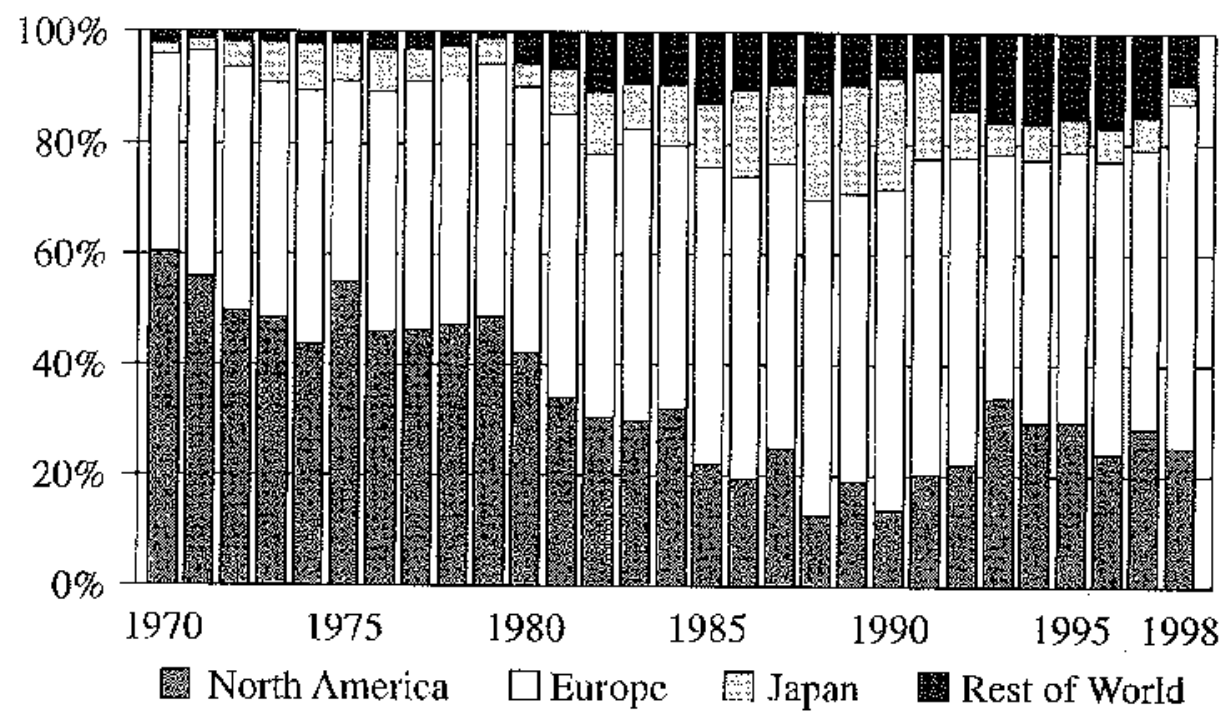

Source: UNCTAD Handbook of Statistics (2000).

Figure 4.3 Outward FDI flows: Triad proportion of total

interest in global capacity diversiffcation in developing economics. Of particular interest is the small fraction of FDI inflows to Japan, indicating the relatively closed nature of its economy. 
The Triad's share of I'DI outflows, shown in Figure 4.3, also demonstrates greater variability than their export share; with decreases occurring in the early 1980 s and mid-1990s. The thirty-year average of the Triad, however, remains above 90 per cent. The general or overall decline in the Triad's share may reffect efforts of developing economies to integrate globally and to increase worldwide capacity and market share.

In gencral, then, the Triad's dominance of trade flows is reproduced in its dominance of FDI flows, as the lriad is the principal source and host of FDI flows.

\subsection{FDI M\&A}

Cross-border mergers and acquisitions accounted for most FDI flows in the late $1990 \mathrm{~s}$. More favourable tax conditions, relaxation of regulations and labour laws, and a changing shareholder culture spurred dramatic increases in cross-border M\&A activity. From 1996 to 1999, as shown in Figure 4.4, M\&A inflows to the Organisation for Economic Cooperation and Development (OECD) nations increased over 280 per cent to US $\$ 718$ billion, while M\&A outflows from the OECD nations increased over 200 per cent to US\$767 billion. In 1999 alone, cross-border M\&A inflows and outflows increased approximately 50 per cent.

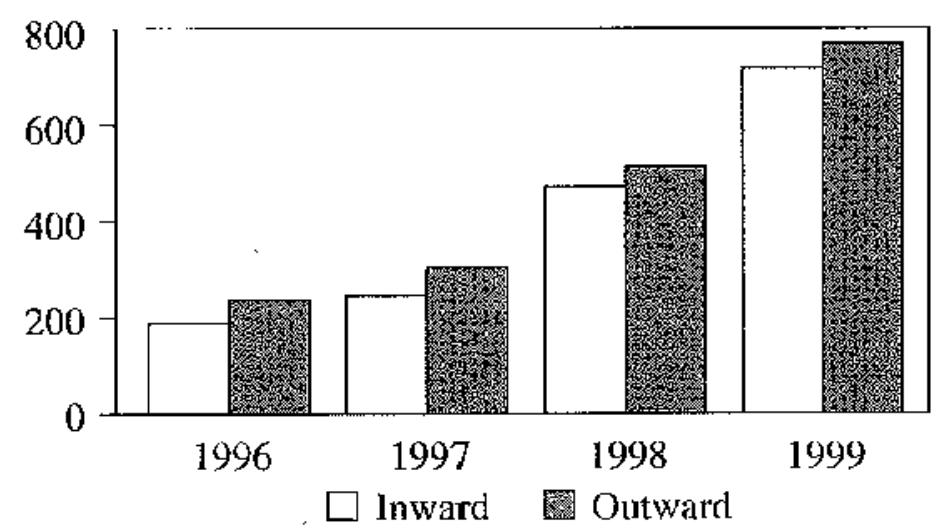

Source: United Nations 1999 World Investment Report.

\section{Figure 4.4 OECD intemational M\&A (\$US billions)}

As shown in Figure 4.5, the majority of M\&A deals were concentrated in the Triad. According to OECD data, in 1999 European companies led in M\&A deals. In the same ycar, the United Kingdom completed more acquisitions than any other nation, accounting for 30 per cent of global M\&A value 


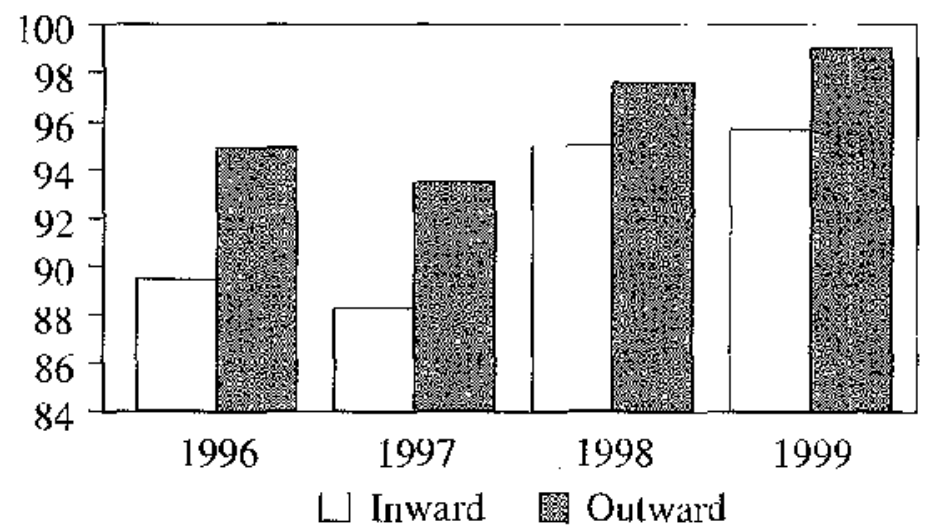

Source: United Nations 1999 World Invesment Report.

Figure 4.5 International $M \& A$ in OFCLD countries: Triad share of total

(Wessel, 2000), while the United States conlinued to attract more M\&A purchasers than any other nation, capturing over 35 per cent of the value of global M\&A purchases.

\subsection{Geographical and Sectoral Distribution of FDI Flows and Cross- Border M\&A}

The recent shift in FDI flows and $M \& \Lambda$ to the Triad nations relative to the rest of the world is illustrated in greater detail in lables 4.2 and 4.3 below, which provide the geographical distribution of FDI inflows and cross-border mergers and acquisitions. We chose not to combine these two measures (that

Table 4.2 Geographical distribution of FDI inflows (percentage of total inflows)

\begin{tabular}{lrrrrrr}
\hline & 1993 & 1994 & 1995 & 1996 & 1997 & 1998 \\
\hline Developed nations & 61.0 & 57.7 & 63.4 & 58.8 & 58.9 & 71.5 \\
$\quad$ European Union & 35.0 & 30.6 & 35.1 & 30.4 & 27.2 & 35.7 \\
Other Furopean nations & 0.9 & 2.7 & 1.8 & 1.8 & 1.9 & 1.2 \\
North America & 22.0 & 21.0 & 20.7 & 23.9 & 26.0 & 32.6 \\
Other developed & 3.1 & 3.4 & 5.7 & 2.8 & 3.8 & 2.0 \\
Developing nations & 35.9 & 39.9 & 32.3 & 37.7 & 37.2 & 25.8 \\
Transitional nations & 3.1 & 2.3 & 4.3 & 3.5 & 4.0 & 2.7 \\
\hline
\end{tabular}

Source: United Nations 1999 World tmestment Report. 
Table 4.3 Geographical distribution of cross-border M\&As, by seller (percentage of total)

\begin{tabular}{lrrrrrr}
\hline & 1993 & 1994 & 1995 & 1996 & 1997 & 1998 \\
\hline Developed nations & 60.3 & 65.8 & 71.0 & 67.9 & 68.4 & 85.9 \\
European Union & 31.9 & 29.7 & 31.5 & 27.9 & 39.1 & 40.6 \\
Other European nations & 0.4 & 1.3 & 0.6 & 1.8 & 1.4 & 1.5 \\
North America & 24.8 & 32.0 & 31.2 & 29.6 & 22.6 & 39.8 \\
Other developed & 3.2 & 2.7 & 7.6 & 8.5 & 5.4 & 4.0 \\
Developing nations & 30.0 & 31.1 & 22.2 & 30.4 & 28.0 & 12.4 \\
Transitional nations & 9.8 & 2.5 & 6.8 & 1.5 & 2.9 & 1.6 \\
\hline
\end{tabular}

Source: United Nations 1999 World Investment Report.

is to express M\&A as a percentage of FDI flows, as is often done), as M\&A may be financed by means other than foreign direct investment, thereby overstating the importance of M\&A as a percentage of FDI. Nonetheless, the data illustrate a significant increase in KDI inflows in the developed nations, and in the Triad in particular, at the expense of developing nations. As in the previous section, the increase in HDI corresponds with the dramatic increase in M\&A activity in the developed nations.

Table 4.2 indicates that the developed countries increased their share of world FDI inflows by an additional 13 per cent and their share of world crossborder M\&A by an additional 17 per cent at the expense of developing and

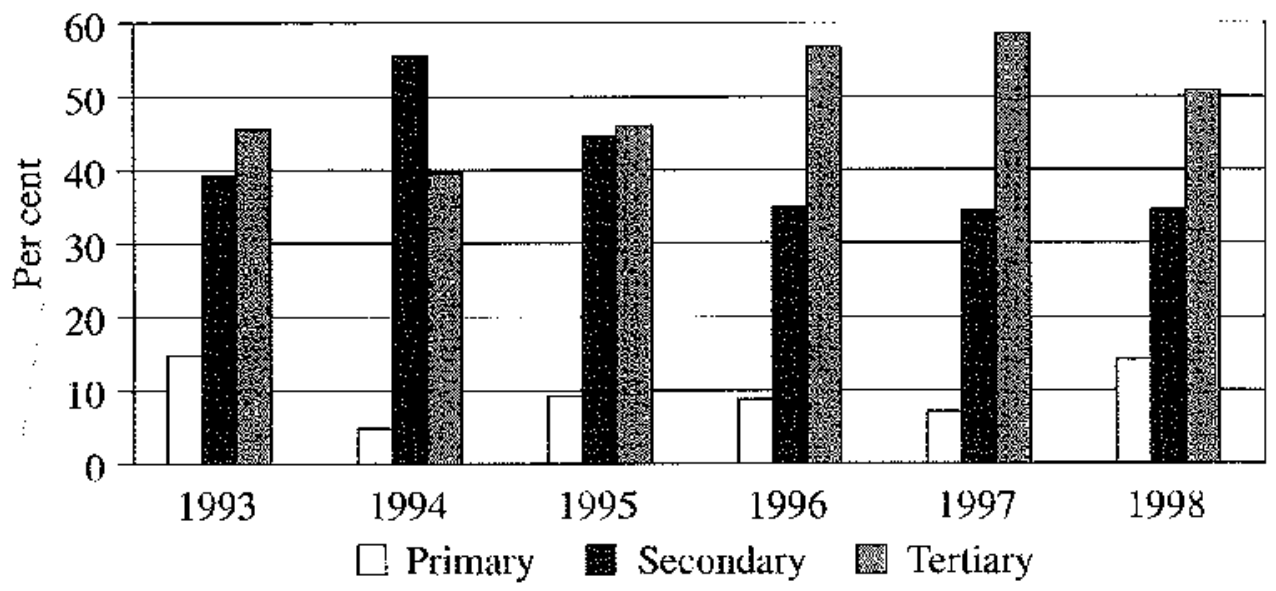

Source: atthor's estimates.

Figure 4.6 Cross-border $M \& A$ by sector (percentage of total) 
transitional nations. This trend is best understood in light of the sectoral distribution of M\&A deals. Figure 4.6 illustrates the distribution of crossborder M\&A by primary, secondary, and tertiary sectors. The growing importance of tertiary M\&A reflects, in particular, recent deals in banking, finance, and related services conducted almost exclusively anong the developed nations.

\subsection{The Relationship Between Foreign Direct Investment and Trade Flows}

Further international cconomic integration is likcly to result from increases in international production capacity due to larger capital flows rather than the expansion of world exports resulting from the reduction of trade barricrs. What might this imply about the relationship between capital flows and trade flows? Not too long ago, business economists believed global expansion occurred along two relatively independent routes: through trade or through foreign direct investment. Global strategies were simple in that a firm could expand internationally by exporting goods and services or by FDI and producing abroad. Recent theoretical and empirical research, however, suggests that the relationship between trade and FDI is more complex, and that trade and foreign direct investment complement each other. FDI may spur greater amounts of trade and trade may spur greater amounts of FDI.

Jantagné and Pajot (1997) provide estimates of the impact of bilateral FDI flows and FDI stocks on bilateral trade flows, controlling for such things as market distance, income levels, and market sizes. Their evidence suggests that Japan's exports to the United States are 149 per cent higher than they would have been in lieu of bilateral FDI flows, while US exports to Japan are 86 per cent higher than they would have been without the bilateral FDl flows. FDI flows between Japan and the United States contribute to a hilateral trade deficit for the United States, as a greater amount of exports to the United States are generated than exports to Japan. ${ }^{2}$ In contrast, the bilateral FDI relationships between Canada, the United States, and the United Kingdom generate approximately equal amounts of imports and exports, and do not accordingly explain trade imbalances between the countries. ${ }^{3}$ This shows that FDI flows may either complement or substitute for trade flows, depending, presumably, on the nature and purposes of the FDI. Below in Section 3, in connection with our discussion of firm strategies, we consider three types of cases in which FDI has specific implications for trade flows. 


\section{UNDERSTANDING THE EVIDENCE IN TERMS OF THE STRATEGIES OF TNCS}

In this section we scck to explain the structural relationships underlying the data on trade and investment in terms of the strategies of major firms in the international economy. According to the 1999 World Investment Report (United Nations Conference on Trade and Investment, 1999), though TNCs include over 500,000 foreign affiliates established by some 60,000 parent companies, a relatively small number of such firms have dominated international production since 1990, with the list of the top 100 firms virtually unchanged since then, of which 90 per cent are from Triad countrics. While the growth of the largest TNCs does not tell the whole story about the globalization of production, their operations are central to it. They dominate world markets for oil, minerals and agricultural products, and play a leading role in the globalization of manufacturing production and services. They also create production and distribution networks in both Triad and non-Triad nations in which small and medium-sized enterprises (SMEs) operate.

\subsection{Change in the Relationship between Trade and Investment}

The data above regarding the growth rates of trade and HDI over the period 1985-1999 provide cvidence of a change in the relationship between trade and investment in the world economy. Our understanding of this development is that uncertain prospects for future trade negotiations have provided an important stimulus for higher levels of l'Dl. Until the Uruguay Round, liberalization of international trade through the General $\Lambda$ greement on Tariffs and Irade (GATT) and the WTO principally targeted the reduction of tariff barriers. But the success of these earlier negotiations created incentives for countries to increase their reliance on non-tariff trade barriers as their principal means of protection. Moreover, because non-tarifl barriers are quantitatively and qualitatively more complex than tariffs, multilateral negotiations for their reduction have been, and are likely to continue to be, less successful than negotiations over reductions in more traditional bariers. The protracted nature of the Uruguay Round, which took up non-tariff barriers, and the largely failed 1999 ministerial talks in Seattle seem to bear this out. Thus, both because countries may rely more heavily on non-tariff barriers, and because progress in reducing such barriers is likely to be slow, firns now have good reason to look upon foreign investment as a key means of continuing expansion.

There may have been a period in the heyday of earlier GATT negotiations when many believed that international economic integration would soon produce a world in which markets for goods, services, and factors of production were perfectly integrated. It has now become apparent that the traditional 
paradigm of a world economy divided into nation states and segmented markets will not be replaced by a borderless world in the foreseeable future (cf. Helliwell, 1998). Trade flows will continue to encounter numerous obstacles, some created by national policies (tariffs and quotas, regulations, national standards, competition policies, and government procurement); some by differences in culture, language, and custom; some by geography (affecting transportation and communication); some by collusive practices of national firms; and others by first entrant advantages (economies of scale, learning by doing, control of distribution systems, privileged access to inputs, and customer loyalties). All of these give rise to imperfect competition, market segmentation, and international price and cost differences. But firms that engage in FDI can take advitrtage of the opportunities of such segnentation and thes arguably the dramatic growth in FDI since the mid-1980s reficets the decision (and the ability) of TNCs to exploit foreign profit opportunities and locational advantages not available through export strategies alone.

'This conclusion may be understood in terms of two of the leading theories. Firsl, il recalls Hymer's emphasis on structural market imperfections and markct power approach (Itymer, 1976), more in regard to the advantages these create for firms than regarding the removal of conflict between them. But an emphasis on market scgmentation also demonstrates the importance of transactions costs, since firms encountering obstacles to trade that invest abroad presumably regard transactions costs as greater than the costs of relocation and organizing production through direct managerial control. $\mathrm{Ob}$ stacles to trade, whether created or natural, cause transaction costs which may be internalized through FDI. We agree with Buckley (Buckley, 1990, p. 658) that 'the internalisation and market power explanations ... should not be viewed as mutually exclusive or competing theories but should be combined to give a full and rich explanation of the growth of multinational firms.'

At the same time, we believe there are advantages in using the transactions cost framework to account for both the concentration of world FDI in the Triad (Section 2.2 above) and also the high degree of M\&A in world FDI (Section 2.3 above). The Hymer framework, with its focus on imperfect competition, would lead us to expect developing countries to be an especially important destination for $\mathrm{F} \mathrm{DI}$, since their markets tend to be less competitive than those in developed countries. But the evidence indicates that developing countries have received a relatively small share of FDI since the mid-1980s. Further, if developing countries were an important destination for FDI, we would expect a higher share of FDI to be grecnfield investment, both because of fewer opportunities in developing countries for M\&A and because of greater opporlunities for investments targeting unexploited resources. But the evidence indicates that greenfield investment, though still important, has been relatively unimportant in world FDI since the mid-1980s. Thus in the 
section that follows we rely on a transactions cost framework to cxplain both the concentration of FDI in the Triad countries and the importance of M\&A in total world FDI. We use this framework in terms of search and deliberation costs taken as a general form of transactions costs.

\subsection{Search and Deliberation Costs as Transactions Costs}

Another way of understanding the obstacles to trade described above is in terms of cross-border information discontinuities that create significant search and deliberation problems for TNCs (Rangan and Lawrence, 1999, ch. 4). Within countries, information flows tend to be smoother and more hornogeneous on account of shared market regulations and culture. Across borders, information flows tend to be irregular and interrupted, so that there may be significant interpretation problems, as differcnt systems of regulation and culture come into contact. In general, search problems arise when firms seek to identify potential customers and suppliers as exchange partners. The costs of search increase not only as potential exchange partners become more physically dispersed, but also because across the international economy culture, language, and custom are different. In general, deliberation problems arise in connection with firms' assessments of the reliability and trustworthiness of potential exchange partners. The costs of deliheration rise as it bccomes more difficult to reverse past decisions, implying that minimizing deliberation costs calls for stable relationships with exchange partners. Clcarly domestic markets typically involve both lower search and deliberation costs for firms. We explain this by saying that domestic markets involve lower costs because firms are embedded (Granovetter, 1985) in established social, cultural, and business networks that help them identify and evaluate those with whom they do business. The lesson this implies is that success in international business similarly depends upon firms becoming embedded in social, cultural, and business networks in foreign locations that reduce search and deliberation costs. We use this insight to emphasize the importance to TNCs of intermalizing search and deliberation costs as a gencral form of transactions costs through cross-border M\&A, FDI, and strategic alliances.

The modern theory of the internationalization of markets in the literature on intertational production (see Buckley and Casson, 1976) draws on Coase's (1937) original contribution establishing transactions cost analysis. One important emphasis in this literature is on intangible assets such as technology that are particularly costly to exchange in arm's-length transactions, and are consequently important candidates for transactions costs intcrnalization. In the international economy, TNCs thus internalize their acquisitions of technology through investment in forcign research and development (R\&D) facilities, particularly through M\&A with foreign firms that already possess 
desirable tacit capabilities that have been organizationally embedded in those firms through collective learning processes. There is a spectrum of such possible arrangements (cf. Kay, 1983). At one end are joint ventures and decentralized TNCs in which internal markets regulated by transfer prices have replaced external markets (Rugman, 1981). At the other end of the spectrum are globally integrated multinationals with foreign affiliates in production and distribution in which control over all divisions and operations is centralized and hierarchical (Williamson, 1975).

Acquisitions of technology, of course, account for only one category of exchange partners for TNCs. Putting aside the transformation of business through technological change, firms also have relationships with suppliers, subcontractors, distributors, labour and management personnel, consultants, and financial institutions in carrying out routine operations. All of these relationships are likely to differ in important respects in foreign country locations as compared to home country locations. The 'foreign-ness' of these relationships, however, is much the same as relationships aimed at technology acquisition. Just as many important technologies involve intangible assets and are embedded in firms through collective learning processes, so the relationships with most exchange partners, domestic or foreign, presuppose lacit understandings and expectations that guide these relationships and get embedded over an extended period of time.

When firms operate in their home locations, they often take these tacit features of exchange for granted. In foreign locations, however, they become sharply aware of the role that tacil understandings and expectations play between business partners. TNC.s, we suggest, are firms that have learned how to identify the implicit features of exchange relationships in foreign countries, and then form relationships with suppliers, subcontractors, distributors, and so on. In doing so, they internalize transactions costs involved in operating supply and distribution chains outside of their home countries, where those transactions costs might be labelled business and economic network transactions costs, and are closely associated with search and delibcration costs of doing business there. As Rugman puts it (Rugman, 2000, pp. 215ff), TNCs serve as 'flagship firms' by operating at the hub of a business network or cluster. Long-term contracts are established with four basic kinds of partners - key suppliers, key customers, key competitors, and the non-business infrastructure - and the whole constitutes a relatively settled business system that internalizes an entire structure of transactions costs, not just transactions costs on a partner-by-partner basis.

The behaviour of US TNCs in manufacturing is illustrative. Although in 1990 the top 50 US TNCs accounted for nearly 40 per cent of US manufacturing exports, exports were not a large share of these firms' overall foreign sales, which were carried out by these finns' foreign affiliates (Fortune, 1991, 
p. 59). In general (see Rangan and Lawrence, 1999, pp. 34ff), US TNCs appear to ship about half of all their exports on an intrafirm basis to their affiliates abroad. Moreover, a very significant share of these exports are inputs awaiting further value-added rather than finished products ready for sale. Some might suppose from this that these US firms have thus simply located production facilities in other countries, and carry out manufacturing operations there with home produced inputs. In fact, however, US input content in sales by foreign affiliates in developed economics is typically low, now amounting to about 10 per cent or less (Rangan and Lawrence, 1999. p. 65). ${ }^{4}$ Thus, US TNCs rely on their developed country forcign affiliates not home exports - for foreign sales, and focus on intrafirm exports of inputs to those affiliates, but then rely primarily upon local sourcing of inputs in generating products for final sale. We believe this illustrates the embeddedness of TNCs, especially in developed economies in which the pervasiveness of search and deliberation costs requires that firms internalize transactions costs on a systemic, wide-ranging basis.

The point stands out more clearly when we compare the practices of US TNCs in developing countries. While these firms rely on their foreign affiliates and less and less on home exports for their foreign sales, when we consider intrafirm exports of inputs to those affiliates, it turos out that TNCs depend less on local sourcing in developing countries. Thus, US input content in 1982 for a selection of developing economies ranges between 15 and 50 per cent (Rangan and Lawrence. 1999, p. 83). In our view, this reflects the lesser extent to which developing economies have established complex social and economic networks into which US TNCs must insert themselves in order to intemalize search and deliberation transaction costs and carry out profitable transactions. Clearly business and economic networks exist in such economies. However, their number and variety of possible exchange partners do not compare with networks in developed economies. Thus we suppose that search and deliberation costs are lower in these economics, so that the expansion of TNCs into these economies reflects less the need to internalize such costs and perhaps more the pursuit of market power advantages à la Hymer. It should be noted, nonetheless, that the general pattern since 1982 is rising local content in US 'INC foreign affiliate production. This suggests that the development of those economies, plus possibly technological spillover effects on local business networks (sce below), is slowly creatiog a business environment for TNCs in developing economies guided by the same factors as those in developed ones.

We would not want to suggest by the analysis above, however, that the social and economic frameworks into which TNCs enter are static in nature and unaffected by this entry. A long literature dating from the earliest studies of TNCs has examined the transformative effects these firms have on local economies. Consider the case of technology transfer. Dunning (1958) pio- 
neered this work in his study of the operations of British affiliates of US TNCs as compared to their British-owned counterparts. The former were generally more successful than the latter, and Dunning argued that this was due to the capacity of 'INCs to transfer often intangible assets (technology, marketing, managerial skills) to their affiliates. Moreover, after a time the British firms were able to catch up with the US affiliates, demonstrating the spillover character of the original transfers.

One way that this spillover may occur is through transformation of TNCsupplier and TNC-distributor relationships. Seeking low-cost input supplies and efficient distribution networks, TNCs transfer organizational methods and technologies to their business partners, who then re-employ these methods and technologies in their business relationships with domestic firms. The latter then change their methods of organization and technologies, and so on. Thus FDI has interrelated transfonmative effects on host countries' technology levcls and systems of business organization. Not surprisingly, developing countries have sought to take advantage of this by imposing local content requirements on TNCs (now generally banned by the WTO under the Agreement on Trade-Related Measures or 'TRIMs). Other 'downstream' spillovers include local human capital development (Borenszstein et al., 1994). Finally, a recent OECD study $(2000$, p. 25) emphasizes the transformative effects of TNC activity in terms of the self-perpetuating nature of FDI. Not only do competing TNCs tend to follow one another into foreign locations, but they are also likely to induce local investments in supply chains and other business service providers. This is important for understanding the emerging role for SMEs operating in conjunction with TNCs in developed countries.

How, then, do these conclusions relate to the structural trends presented in Section 2 above'? What stands out is the concentration of trade and investment in the Triad, the importance of $M \& \Lambda$, and (to a lesser extent) the rising importance of tertiary production in FDl activity. Based on the discussion above, our argument regarding these trends is two-sided. First, though the obstacles to FDI as contrasted with domestic investment place a special burden on TNCs 10 overcome cost disadvantages in entering foreign locations, that burden may be eased through exploitation of search and deliberation transaction cost savings when these firms succeed in embedding themselves in foreign business and economic networks. We thus conclude that because these networks are more highly developed in the Triad, the opportunities for expansion there are greater. Second, once embedded in these networks, our analysis suggests that there is considerable promise of profitable returns on TNC investments, because highly developed business networks offer firms the flexibility to regularly adjust their commitments with exchange partners, which should be to their advantage. We believe the level of M\&A FDI in the 
Triad particularly reflects this. The embeddedness/transactions cost framework, then, takes us a considerable way toward understanding firm strategics responding to and underlying recent structural changes in the world economy.

\subsection{Firm Strategies Producing FDI and Trade Flow Linkages}

With our conclusions about TNC strategies developed above, we return to the topic of whether trade and investment are substitutes and/or complements, and describe three cases in which firm investment decisions have implications for countries' exports and imports. The importance of the topic lies in how countries assess the costs and benefits of liberalizing capital flows when the eflects include changes in their trade accounts. In our view, one obstacle to successful international negotiations over capital flows liberalization is uncertainty regarding whether higher FDI creates trade deficits. The case has been made more frequently for capital-exporting countries, but it has also been made for capital-importing countries. Here we do not provide a comprehensive analysis of the subject, but rather suggest by our three cases that the effects of FDI on trade depend upon the purposes for which FDI is carried out. Trade and investment may thus be substitutes and/or complements for one another according to the circumstances involved, and we may accordingly rule out the impact of FDI on countries' trade balances as a policy concern.

First, consider perhaps the simplest type of relationship between FDI and trade. A firm moves production from a home location to a foreign location, and replaces its home exports with foreign affiliate sales. 'The home country trade account may be more or less unaffected, if some home input suppliers now export to the new foreign location, and prior imports of inputs to the home location now fall. The host country may lose exports if it was an input supplier to the original location of production in the home country, and sce some added input imports, but may also gain exports if the new plant employs new technologics that make it possible to add capacity to export. Thus the overall effects depend on the character of the original investment, and there does not appear to be a general relationship between FDI and trade.

Second, consider the case of a developed country firm that moves labourintensive production to a foreign location, and then imports the output for final assembly at home. Since final output is now cheaper, the export capability of the firm is enhanced. The home country may thus increase its imports and also its exports. At the same time, the country to which the labourintensive production was relocated now has higher exports. But if, as is not unlikely, it purchases the now relatively cheaper output of the home country firm, then its imports rise as well. Thus the ultimate impact on trade of FDI again depends upon the kind of FDI and the circumstances involved. 
Third, consider the trade effects of using FDI to outsource stages of the production process in pursuit of cost advantages in foreign locations (Fecnstra, 1998; Davis and Daniels, 2000). Though attention is often focused on the stages of production that leave a home country, equally important for understanding the trade effects of FDI are those stages of production that it retains. When a country retains stages of the production process in which it lacks comparative advantage, the possible comparative advantage it possesses in other stages may be concealed by a focus on whether the final product is cost competitive. Conversely, when a country relocates stages of production in which it is not cost competitive, say, simple assembly in developed countries, then those remaining stages in which it is especially cost competitive, say, marketing and design stages, become a more obvious source of export earnings. In these circumstances, imports rise when the output of foreign assembly operations is brought back to the home country to produce the final product, but exports may also rise if firms exploit the foreign marketability of business services in which they have comparative advantage. The increasing importance of tertiary cross-border M\&A may reflect this re-positioning of firms in developed countries in the higher value-added stages of the production process. Thus again, the ultimate impact on trade of FDl depends on the character of the investment.

\subsection{Policy Toward FDI and TNCs}

TNCs have been characterized as firms that have shed their home-nation identities and operate essentially as stateless entities (Ohmae, 1990). This has led to a concern that TNCs will locate operations wherever in the world they are able to minimize costs, making it increasingly difficult for nations to tax TNCs, thus resulting in a shifting of tax burden from capital to labour (Rodrik, 1997). The implication of these views and arguments is that further liberalization of regulations on capital flows and entry of foretgn firms into domestic markets and on FDI, such as was involved in the efforts within the OECD to develop an MAI, is undesirable (see, for example, Brannstein and Epstein, 1999). ${ }^{5}$ On the other side of the debate, Swank (1999) las argued that international capital mobility and the internationalization of capital markets necd not jeopardize the institutions of the wellare state, since democratic institutions that facilitate collective representation of interests may structure governmental responses to ' 1 'NC strategies. Relatedly, others have argued that the development of new forms of corporate governance as promoted by a variety of NGOs can also help accommodate the international economy to significant social and environmental needs (for example, Nadkami, 1999).

To sort out this debate, we first emphasize the difference between FDI and portfolio investment, then discuss the difference between national compeli- 
tiveness and the competitiveness of a nation's firms, and finally close with an argument in favour of the ultimate objectives of the MAI. Our argument is that because FDI has a stabilizing influence on national economies, and because the competitiveness of nations is enhanced by inward FDI flows, careful liberalization of long-term capital flows, such as was intended by the MAI, is desirable. However, the venue and form of such an agrecment remain an issue,

\subsection{FDI versus Portfolio Investment}

It is important to emphasize the economic difference between portfolio and FDI lows. Portfolio flows as a non-ownership, liquid form of investment, are easily reversible, whereas FDI as a relatively illiquid, ownership form of investment typically involves long-term commitment. Significant portfolio inflows can, and often do, overwhelm a nation with an inefficient or under-developed system of financial intermediaries, and the allocation of this new source of liquidity may often be economically unsound. Worse, as learned in the 199495 Mexican and 1997 East Asian financial crises, when portfolio flows slow or reverse, the system of intermediaries then often becomes illiquid and a financial crisis may ensue (sec Chang and Velasco, 1998). In the case of Mexico and the rest of the western hemisphere's emerging economies, porffolio flows increased relative to FDI from 1990 to 1994 . Following the crisis that began in December 1994, the outflow of portfolio capital resulted in a 112 per cent decline and overall negative net portfolio flows for the region. When portfolio flows reverse in one nation, they often trigger a crisis in the entire region, as seen in the cases of Mexico and Thailand. Empirical work by Glick and Rose (1998) indicates that currency crises affect 'clusters' of nations, working through established trade channels. Hence, over-reliance on portfolio capital can be destabilizing for individual countrics and entire regions.

In contrast, FDI appears to be a stabilizing factor. When TNCs establish foreign affiliates or cnter into stratcgic alliances, they scek long-term commitments. Search costs are reduced, because participation in host country networks transfers information within the network regarding customers and suppliers that is not available to firms engaged in arm's-length trade. Deliberation costs are reduced, when long-term relationships reduce the need to regularly evaluate potential exchange partners. Thus one would not expect TNCs to enter and exil foreign countries with high degrees of frequency. Indeed, as it is more difficult to enter into forcign business and market networks than in home countries, exit from established facilities and operations seems less likely in foreign locations. Against the argument that tax costs create footloose 'lNCs, it seems that tax costs are a relatively minor element in decision-making regarding the location of production. FDI and 
TNCs, then, appear to have a stabilizing influence on the economies in which they locate, bringing income and cmployment to those cconomies.

\subsection{National Competitiveness versus a Nation's Firms' Competitiveness}

Despite arguments that TNCs have dissociated themselves from their national origins, many still believe that national economic strength is linked to the success of a country's TNCs. Thus whether or not these firms are internationally competitive is an importint neeasure of whether nations are competitive in the world cconomy. But there are good reasons to think this emphasis on a nation's firms is misplaced. Reich (1990) asks us to consider the positive impact that foreign firms have on a country's employment and income when they locate production or distribution subsidiaries in that country. Of course the opposite impact occurs when foreign firms leave a country, but Reich thinks that seeing exit as an incvitable consequence of entry misconceives the Inture of FDI. Firulus invest in foreign markets because they perceive advantages to doing so: skilled workforces, good distribution networks, developed supply chains, access to finance, and so on. A country that invests in education, research, training, and infrastructure, then, can expect to continually attract FDI, enabling it to maintain high levels of employment and income. If we add the benefits of technology spillovers discussed above, we might imagine a virtuous spiral of growth and investment, whereby domestic investment and FDI continually reinforce one another.

Reich's argument is mostly pitched at a macroeconomic level. Our argument emphasizes the factors affecting firms' decision-making regarding where they wish to locate their subsidiaries and develop strategic alliances. In virtue of the importance of business and economic networks in a foreign venture, firms will generally be reluctant to abandon commitments to an interlocked complex of exchange partners, both because of the original cost of building up that set of commitments and because of the anticipated cost of having to re-establish similar commitments elsewhere. Seen in this light, Reich's recommendation that nations pay less attention to who owns firms and more attention to creating the economic conditions in which all firms will prosper, is tantamount to a call for govermments to help bear the cost of setting up such networks. In effect, Reich recommends that governments socialize search and deliberation costs for firms (foreign and domestic) through public goods expenditures, in order to help create national and regional business networks that rival those elsewhere. ${ }^{6}$

One important implication of this is that FDI appears to have a greater stabilizing influence on national economies than some of its stronger proponents have supposed. Indeed, FDI may be argued to move more inertly than 
even domestic long-term investment flows, since domestic firms inherit a variety of home country advantages that enable them to move across different national business networks, providing them with consistently lower search and deliberation costs than foreign firms have in those same networks. To be competitive, then, foreign firms need to be more successful than domestic firms in internalizing search and deliberation cosis, and consequently they need to be more committed to building up their involvement in the networks in which they participate. TNCs, then, should be quite reluctant to exit from foreign locations in which they set up operations, and when they do find this their best course of action, it is likely that there are deeper causes at root having to do more with national economic policies than the liberalization of long-term capital flows.

\subsection{The MAI}

There is currently no comprehensive set of international rules on FDI or the operations of TNCs comparable to the international rules for trade embodied in the WTO, and progress in multilateral negotiations on the subject has been modest at best. Issues relating to host country policies toward FDI and TNCs were first raised in GATT discussions in 1981, and by the lime of the WTO Unuguay Round a limited set of trade-related investment measures (TRIMs) principally conceming local content restrictions had been agreed upon. Somewhat more success in the Uruguay Round came about in conncction with trade-related intellectual property policies (TRIPs), perhaps because developing countries were prepared to encourage technology transfers from developed countries. However, the perception of many in the industrial countries was that further progress in liberalizing capital flows was unlikely to occur within the WIO on account of the different interests of developed and developing countries (Graham, 1996). Accordingly, in 1994 an elfort began to work out an agreement on investment within the OECD, where it was believed there was greater commonality of interest. The collapse of negotiations over the MAI in late 1998 thus gencrated considerable pessimism not only about progress in liberalizing capital flows, but also in terms of where efforts ought to be initiated. Nll now seem to agree that limited negotiations hold the only prospect. Two proposals have been advanced for returning to the WIO as the proper venue for such negotiations, and relying on the WTO's 'built-in' agenda to avoid the need for authorizing any new initiatives.

Moran (1998) has argued for restricting the agenda to performance requirements and investment incentives within the context of the cxisting TRTMs agreement. The former are of particular concern to developed countries and the latter are of particular concern to developing countries. Thus in principle there is potential for an agreement with reciprocal concessions. But it is by 
no means clear that the two sets of countries will be able to bargain as blocs. For example, developed countries include federal and non-federal forms of government. The former, particularly the United States, have insisted that they cannot compel subfederal governments (states) to restrict invesment incentives. In addition, a number of developing countrics appear unwilling to compromise on performance requirements.

Sauve and Wilkie (2000) have argued that a restricted agenda can be pursued through the WTO General Agreement on Trade in Services (GATS) by applying national treatment in services. They contend that the current GATS agreement is quite limited in scope, and that most countries' laws and policies that are inconsistent with national treatment are to be found in service industries covered by GATS (ef. Ringman and Gestrin, 1994). Graham (2000) argues in favour of this initiative on the grounds that the chief application of the proposal would be to developed countries, between which it might be more realistic to seek agreements on the matter, and there appears to be a very considerable business constituency interested in services liberalization.

We favour progress on both these fronts, but think it is also possible to extend piccemeal reform in venues additional to the WTO. In his diagnosis of the Asian financial crisis, Eichengreen (1999) argues for a reform of international financial intermediary and corporate ptactices that would increase banking and corporate transparency and disclosure through enhanced accounting and auditing standards, establish capital requirements for forcign lending in line with risk, and generate new expectations regarding corporate governance. But Eichengreen does not suggest that the Intemational Monetary lund or any other single international organization take on responsibility for all these changes. Rather, he believes a collection of private-sector bodies with appropriate expertise already exists, including: the International Accounting Standards Commiltee (IASC), the International Organization of Supreme Audit Institutions (INTOSAI), Committec I of the International Bar Association (regarding bankruptcy laws), the International Corporate Governance Network (ICGN), the International Organization of Securities Commissions (IOSCO), and the Basle Committee on Banking Supervision (also cf. Daniels, 2000a, p. 127).

Reform in the international financial architecture generated by these groups and organizations would not in itself constitute a liberalization of international investment. But such reform would most likely create a more stable international climate for investment. On the one hand, such reform would ease information asymmetries that impede FDI. On the other hand, to the extent that national currencies were more stable as a result of such reforms, investment risk would be reduced. Thus, if only modest gains are now expected from negotiations over investment carried on in multilateral 
organizations such as the WTO, these potential improvements in international financial architecture may by comparison be important. There is a further reason to emphasize this avenue. Since the groups and organizations above are private-sector bodies, their deliberations and decisions are unlikely to cause the sort of conflict that has been associated with the WTO. Moreover, should these groups and organizations be subject to public scrutiny, it is still arguable that their recommendations would not be controversial.

\section{SUMMARY}

In this chapter we present a collection of stylized facts regarding structural changes and developments in the world economy in connection with trade, FDI, M\&A, and their distribution across the Triad and the ROW, and then provide an explanation of TNC strategies responding to and underlying these trends that exphasizes the transactions costs savings available to TNCs that become embedded in host economies. In our view, this picture provides good grounds for supposing that FDI and trade are substitutes and complements, and thus that the impact of FDI on trade balances should not be a primary policy concern. In the concluding section, then, we discuss policy toward FDI, and argue that the embeddedness of TNCs makes FDI a stabilizing factor in national economics. Despite this positive case, progress in liberalizing international capital lows has not been signilicant. We favour a set of piecemeal reforms, including changes in international financial architecture that stem from private-sector bodies.

\section{NOTES}

1. Globalization should be understood in terms of the interdependence of trade and invest-ment within as well as befween regions (Rugman, 2,000).

2. This relationship between FDI and trade in the case of Japan and the United States may be transient, since Japan appcats to bc moving from a bank-based system of coporate govern ance to a more securities-based systelt - a change which would have implications for Japanese FDI and trade (see Ozawa, 2000).

3. Ilowever, the FDI relationship between the United Kingdom and Canada results in slightly lower 1rude llows than would have occurred without FDI taking place.

4. The exceptions are Canada and Japan. Nor is the US case unreflective of the behaviour of non-US INCs, with forcign content in salcs by their US affiliates also in the neighbour hood of 10 per cent.

5. Note that the issues often raised in comnection with FDI to developing countries of labour cxploitation and environmental damping ate not relevant to the MAI, which was an agreement being regotiated between developed countries.

6. Here we see one of the important dimensions of Ruguran's (2000) characterization of globalization as a process of regionalization. 


\section{REFERFNCES}

Bhagwati, J. and V. Dehejia (1994), "Freer trade and wages of the unskitled - is Marx striking again?', in J. Bhagwati and M. Kosters (eds), Trade and Wages: Leveling Wages Down?, Washington: Anerican Enterprise Institute, pp. 36-75.

Borenszstein, E., J. De Gregorio and J. L.ee (1994), How Does Foreign Direct Investment Affect Economic Growth?, Washington: International Monetary Fund Working Paper WP/94/110.

Braunstcin, E. and G. Epstein (1999), 'Crcating international credit rules and the Multilateral Agreement on Investment: what are the alternatives?', in J. Michic and J.G. Smich (eds), Global Instability. The Political Economy of World Governance, I ondon: Routledge, pp. 113-33.

Buckley, P. (1990), 'Problems and developments in the corc theory of international business', Journal of International Business Studies. 21 (4), pp. $657-65$.

Buckley, P. and M. Casson (1976), The Future of the Multinational Enterprise, London: Macmillan.

Cantwell, J., T. Corley and J. Dunning (1986), 'An exploration of some historical antecedents to the modern theory of intentational production', in G. Jones and $P$. Hertner (eds), Multinationals: Theory and History, Harnborough: ( jower.

Chang, R. and $\Lambda$. Velasco (1998), 'The $\Lambda$ sian liquidity crisis', Federal Reserve Bank of Allanta Working Paper, n10. 98-11.

Coase, R. (1937), "The nature of the firm", Economica, 4 (4).

Daniels, J. (2000a), 'Global capital flows: maximising benefits, minimising risks', in Kall Kaiser, John Kirton and Joseph Daniels (eds), Shaping a New International Financial System: Challenges of Governance in a Globalizing World, Aldershot: Ashgate, pp. 113-33.

Daniels, J. (2000b), 'The United States and global capital markets', in T. Brower and G. Boyd (eds), Globalizing America: The USA in World Integration, Cheltenham, UK and Lyme, US: Edward Elgar, pp. 154-72.

Davis, J. and J. DanieIs (2000), 'US corporations in globalization', in S. Cohen and G. Boyd (eds), Corporate Governance and Globalization: Long Range Planning Issues, Cheltenlsam, UK and Lyme, US: Edward Elgar, pp. 190-215.

Dunning, J. (1958), Anerictn Investment in British Manufacturing Industry, London: Allen \& Unwin.

Dunning, J. (1977), 'Trade, location of economic activity, and the MNE: a search for an eclectic approach', in I3. Ohlin, P.-O. I Jesselborn, and P.M. Wijkman (eds), The International Allocation of Economic Activity, London: Macmillan.

Dunning, J. (1981), Intemational Production of Multinational Enterprises, London: Allen \& Unwin.

Dunning, J. (1988), "The eclectic paradigm of international production: an update and a reply to its critics'. Journal of International Business Studies, 19 (1).

Eichengreen, B. (1999), Toward a New Intemational Financial Architecture: A Practical Post-Asia Agenda, Washington: Institute for International Economics.

Fantagné, L. and M. Pajot (1997), 'How Foreign Direct Investment affects international trade and competitiveness: an empirical assessment', CEPII Working Papers, November, no. 97-03.

Feenstra, R. (1998), 'Integration of trade and disintegration of production in the global economy", Journal of Economic Perspectives, 12 (4), pp. 3150.

Fortune (1991), 'Top 50 U.S. Exporters', Summer-Spring. 
(ilick, R. and A. Rose (1998), 'How do currency crises spread?', Federal Reserve Bank of San Francisco Economic Letter, no. 98-25.

Graham, E. (1996), Global Corporations and National Ciovernments, Washington, DC: Institute for International Economics.

Graham, E. (2000), Fighting the Wrong Enemy: Antiglobal Activists and Multinational Enterprises, Washington: lisstitute for International Econonics.

Granovetter, M. (1985), 'Lconomic action and social structure', American Journal of Sociology, 91 (November), pp. 481-510.

Helliwell, J. (1998), How Much Do Nationat Borders Matter?, Washington, DC: Brookings.

Ilymer, S. (1976), The Intemational Operations of National Firms, Cambridge, MA: MIT Press.

Kay, N. (1983), 'Review article: multinational enterprise', Scotrish Joumal of Political Economy, 30 (3).

Moran, T. (1998), Foreign Direct Investment and Development: The New Policy Agenda for Developing Countries and Economies in Transition, Washington: Institute for International Economics.

Nadkarni, A. (1999), 'World Trade Liberalisation: national autonomy and global regulation', in J. Michie and J.G. Smith (eds), Global Instability. The Political Economy of World Governance, London: Routledge, pp. 134-50.

OECD (2000), 'Recent trends in Foreign Direct Investment', Financial Market Trends, 76 (June), pp. $23-41$.

Ohmae, K. (1990), Borderless World: Power and Strategy in the Interlinked Economy, New York: Harper.

Ozawa, T. (2000), 'Japanese firms in deepening integration: evolving corporate governance', in S. Cohen and G. Boyd (eds), Corporate Governance and Globalization: Long Range Planning Issues, Cheltenham, UK and Lyme, US: Edward Elgar, pp. $216-44$.

Rangan, S. and R. Lawrence (1999), A Prism on Globalization: Corporate Responses to the Dollar, Washington, DC: Brookings.

Reich, R. (1990), 'Who is us?', Harvard Business Review, January February, pp. 5364.

Rodrik, D. (1997), Has Globalization Gone Too Far?, Washington, DC: Institute for International Economics.

Rugman, A. (1981), Inside the Multinationals: The Economics of Internal Markets, London: Croom Helm.

Rugman, A. (2000), 'From globalisation to regionalism: the Foreign Direct Investment dimension of international finance', in K. Kaiser, J. Kirton, and J. Daniels (eds), Shaping a New International Financial System: Challenges of Governance in a Globalizing World, Aldershot: Ashgate, pp. 143-57.

Rugman, A. and M. Gestrin (1994), 'NAFTA's treatment of foreign investment', in A. Rugman (ed.), Foreign Investment and NAFTA, Columbia, SC: University of South Carolina Press.

Sauvé, P. and C. Wilkie (2000), 'Investment liberalization in G $\Lambda T S$ ', in P. Sauvé and R. Stern (eds), GATS 2000: New Directions in Services Trade Liberalization, Washington: Brookings.

Swank, D. (1999), 'Global capital, democracy, and the welfare state: why political institutions are so important in shaping the domestic response to internationalization', Working Paper 1.66, Center for lnternational Studies, Harvard University, University of California Center for German and European Studies. 
United Nations Conference on Trade and Development (1999), World Investment Report 1999, New York and Geneva: United Nations.

United Nations Conference on Trade and Development (2000), Handbook of Statistics, New York and Gencva: United Nations.

Wessel, David (2000), 'Cross-border mergers soared last year', Wall Stret Journal, 19 July, p. A18.

Williamson, J. and M. Mahar (1998), 'A survey of financial liberalization', Essays in International Finance, no. 211, Princeton: Intcrnational rinancial Section, Department of Economics, Princeton University.

Williamson, O. ([975), Markets and Hierarchies; Analysis and Antitrust Implications, New York: Free Press. 